\title{
Spatial analysis on tuberculosis and the network of primary health care
}

\author{
Análise espacial em tuberculose e a rede de atenção primária em saúde \\ Análisis espacial en tuberculosis y la red de atención primaria en salud
}

\section{Beatriz do Nascimento Leal' \\ ORCID: 0000-0002-1784-4387}

Cristal Ribeiro Mesquita"

ORCID: 0000-0002-1321-5719

Laura Maria Vidal Nogueira' ORCID: 0000-0003-0065-4509

Ivaneide Leal Ataide Rodrigues' ORCID: 0000-0001-9968-9546

Lívia Félix de Oliveira"'

ORCID: 0000-0003-1119-4640

Rosinelle Janayna Coelho Caldas' ORCID: 0000-0001-6988-0905

'Universidade do Estado do Pará. Belém, Pará, Brazil. "Instituto Evandro Chagas. Belém, Pará, Brazil. "'I Fundação Santa Casa de Misericórdia. Belém, Pará, Brazil.

How to cite this article: Leal BN, Mesquita CR, Nogueira LMV, Rodrigues ILA, Oliveira LF, Caldas RJC. Spatial analysis on tuberculosis and the network of primary health care. Rev Bras Enferm. 2019;72(5):1197-202. doi: http://dx.doi.org/10.1590/0034-7167-2017-0897

Corresponding Author:

Beatriz do Nascimento Leal

E-mail: bia_leal@live.com

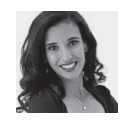

Submission: 02-15-2018 Approval: 04-26-2018

\begin{abstract}
Objective: to analyze the spatial distribution of new cases of tuberculosis compared to the location of the Primary Healthcare Units that performed the compulsory notification. Method: ecological study conducted in Belém, Pará, with 5,294 new cases of tuberculosis notified to Sistema de Informação de Agravos de Notificação for the period from 2010 to 2014. The cases were georeferenced using the software applications ArcGis 10.2 and TerraView 4.2.2. The techniques of Kernel density and global Moran geostatistics were used. Results: the incidence of tuberculosis cases did not vary significantly between the years studied, however there was a variation in incidence between neighborhoods. Health units that exhibited higher number of notifications can suffer great influence of migration from nearby neighborhoods. Conclusion: the spatial dynamics of tuberculosis associated with health services allows to know the areas with increased risk of tuberculosis and the density of notifications of health units. Descriptors: Tuberculosis; Spatial Analysis; Primary Health Care; Public Health; Nursing.
\end{abstract}

\section{RESUMO}

Objetivo: analisar a distribuição espacial dos casos novos de tuberculose relacionando-os com a localização das Unidades de Atenção Primária em Saúde que realizaram a notificação compulsória. Método: estudo ecológico realizado em Belém, Pará, com 5.294 casos novos de tuberculose notificados ao Sistema de Informação de Agravos de Notificação no período de 2010 a 2014. Os casos foram georreferenciados por meio dos softwares ArcGis 10.2 e TerraView 4.2.2. Foram usadas a técnica de densidade Kernel e a técnica geoestatística Moran global. Resultados: a incidência de casos de tuberculose não variou de forma significativa entre os anos estudados, porém houve uma variação da incidência entre os bairros. As unidades de saúde que exibiram maior número de notificações podem sofrer grande influência da migração dos bairros vizinhos. Conclusão: a dinâmica espacial da tuberculose associada aos serviços de saúde permite conhecer as áreas com maior risco de tuberculose e a densidade de notificações das unidades de saúde.

Descritores: Tuberculose; Análise Espacial; Atenção Primária em Saúde; Saúde Pública; Enfermagem.

\section{RESUMEN}

Objetivo: analizar la distribución espacial de los nuevos casos de tuberculosis, relacionándolos con la ubicación de las Unidades de Atención Primaria en Salud que realizaron la notificación obligatoria. Método: estudio ecológico realizado en Belém (Pará, Brasil) con 5.294 nuevos casos de tuberculosis notificados al Sistema de Información de Agravios de Notificación (Sinan) en el período del 2010 al 2014. Los casos fueron georreferenciados por medio de los programas informáticos ArcGis 10.2 y TerraView 4.2.2. Se emplearon la técnica de densidad Kernel y la técnica geoestadística Moran global. Resultados: la incidencia de casos de tuberculosis no presentó variación significativa entre los años estudiados, sin embargo hubo una variación de la incidencia entre los barrios. Las unidades de salud que presentaron un mayor número de notificaciones pueden sufrir gran influencia de la migración de los barrios vecinos. Conclusión: la dinámica espacial de la tuberculosis asociada a los servicios de salud permite conocer las áreas con mayor riesgo de tuberculosis y la densidad de notificaciones de las unidades de salud.

Descriptores: Tuberculosis; Análisis Espacial; Atención Primaria en Salud; Salud Pública; Enfermería. 


\section{INTRODUCTION}

The spatial distribution of the endemic diseases is and study object of geographical epidemiology. Currently, research linking these diseases to their geographic spaces have become of great importance for science, because the dynamics of space influences the occurrence and maintenance of diseases, as well as the existence and the effectiveness of healthcare units. The use of technologies based on geographic information systems (GIS) is a contribution alternative to the understanding of distributive dynamics of tuberculosis cases (TB) ${ }^{(1)}$. Although they were created in the past decade, the GIS still are little used in health. Its use is a start for the development of models that plot the locations where there is risk of diseases, especially TB, being an important tool for the management and planning of health policies ${ }^{(2)}$.

Tuberculosis is still a major public health problem in Brazil and calls attention to health authorities worldwide. The disease is closely linked to socioeconomic issues of the population ${ }^{(3)}$. It affects all age groups, especially in economically active individuals (from 15 to 54 years) and male ${ }^{(4)}$.

Brazil occupies the 18th position in TB occurrences, representing $0.9 \%$ of estimated cases worldwide, and $33 \%$ of the estimated for the Americas. In the state of Pará, seven municipalities are considered a priority for the National Tuberculosis Control Program (PNCT). The average incidence rate was of 31 cases in Pará per 100 mil inhabitants in 2015. The municipality of Belém, capital of the state, presented an incidence rate of 45.8 per 100 mil inhabitants, accounting for half of all new cases in Pará(5-6).

According to the Atlas of Human Development from 2013,74\% of Brazilian municipalities have high and medium human development index $(\mathrm{HDI})$, where $50 \%$ of the municipalities in the North region of Brazil have medium HDI. The city of Belém, in 2010, presented high $\mathrm{HDI}, 0.746$, being higher than the national average of $0.727^{(7)}$.

The GIS is defined as a set of data collection technologies that produces demographic information and contributes to the recognition of the risk conditions in the territory. It became a valid instrument to assist in the construction of maps and help in planning, monitoring and evaluation of health actions ${ }^{(8)}$.

\section{OBJECTIVE}

To analyze the spatial distribution of new cases of tuberculosis according to the location of the Primary Healthcare Units (PHU) that performed compulsory notification.

\section{METHOD}

\section{Ethical aspects}

This study followed the precepts of the National Health Coun$\mathrm{cil}^{(9)}$ Resolution No. 466 of December 12, 2012, and was approved by the Research Ethics Committee of the Nursing School of the State University of Pará in November 11, 2015.

\section{Design, study site, and period}

This is an ecological study conducted in the municipality of Belém, capital of the state of Pará, which is located in the North region of Brazil, and it has 71 neighborhoods. The study period was between 2010 and 2014.

\section{Population, sample, inclusion and exclusion criteria}

The study population was constituted by 5,374 new cases of TB notified to the Health Information System (Sinan) by the Municipal Health Department of Belém (Sesma). Having access to the database, 80 cases that did not present address or were partially filled were excluded, resulting in a sample of 5,294 cases. All new cases of TB from residents of the municipality of Belém that had address registered in the compulsory notification file of PHC units were included. Retreatment cases due to relapse and readmission after deliberate discharge were excluded, as well as those from other municipalities and those notified in hospitals.

\section{Study protocol}

The study was developed based on data collection in secondary sources in the public and restricted domains corresponding to the cartographic data obtained in the Geocentric Reference System for the Americas (Sirgas) in 2000, and the population data obtained in the 2010 Census, both made available by the Brazilian Institute of Geography and Statistics (IBGE). The epidemiological data related to the notification of TB cases in Sinan from Datasus were obtained, made available by Sesma. The following variables were studied: year of notification; notifier PHC unit; the patient's neighborhood of residence; neighborhood where PHC unit is located; full address of TB cases and PHC units.

\section{Analysis of results and statistics}

Initially, the 5,294 cases that were georeferenced using the system of the National Address List for Statistical Purposes (CNEFE - IBGE). The digital maps used were obtained through data from the Company for the Development and Administration of the Metropolitan Area of Belém (Codem), Google Maps, and IBGE.

In the second step, the data obtained from the program TabWin 36b were filtered, which resulted in a Geographic Database (BDGeo). In the third step, we used the applications ArcGis 10.2 and TerraView 4.2.2 for generating the coefficient of incidence in patients with TB in the study area, as well as its visual expression in digital maps.

For calculating the incidence, the number of TB cases and population data from the 2010 Census were used, being multiplied by 100 mil. In this way, the maps were classified into four categories: low (less than or equal to 3); medium (3 to 11); high (from 11 to 71); and very high (greater than 71), following the national cartographic standard.

In the fourth stage, the Kernel density interpolator with adaptive radius and quartic function - a geostatistics technique used to analyze the behavior of dot patterns, providing, through interpolation, the punctual intensity of TB incidence throughout the study area - was used.

As a result, the geostatistics technique of global Moran was used to identify if there was spatial correlation between areas according to the presence or absence of TB cases. A p-value $<0.05$ 
was adopted for global Moran analysis in order to validate the hypothesis of geostatistic significance of the possible correlation.

\section{RESULTS}

Figure 1 presents the pattern of TB in the years of 2010-2014 in Belém-PA, showing that TB incidence had no significant variation from year to year during the period studied. The year 2011 was the year that presented the highest number of TB cases, namely 1115.

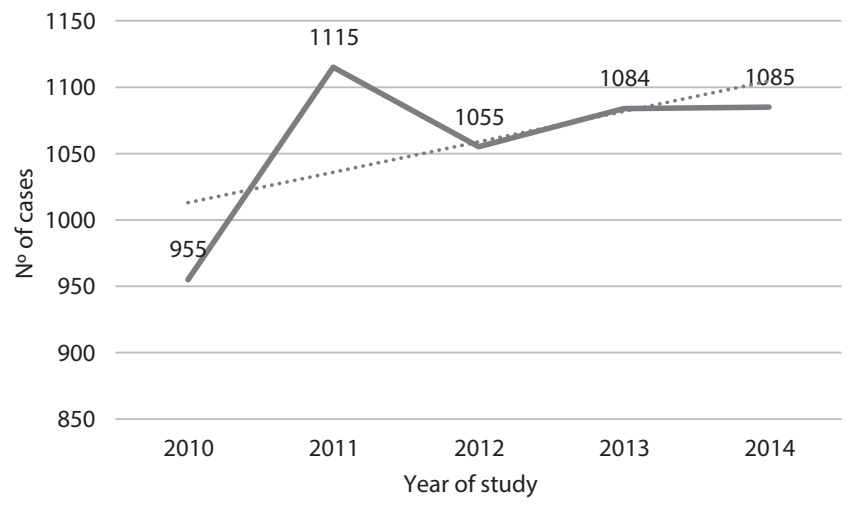

Source: Sinan, 2016

Figure 1 - Graph of the number of tuberculosis cases in the period between 2010-2014, Belém, Pará, Brazil

Figure 2 shows a grouped spacial pattern, encompassing all the cases of all years analyzed. Eight clusters were present, being evidenced by the color gradient. The clusters observed are the neighborhoods: Montese (18), Guamá (5), Jurunas (8), Telégrafo (21), Pedreira (20), Sacramenta (22), Marambaia (29) and Tapanã (39), with high TB density (> 200 cases). However an interpolation of points was observed between the neighborhoods of Sacramenta (22) and Barreiro (23), which can be related to any event present in the area that justifies this fact, given the socioeconomic aspect.

Areas surrounding clusters, situated between the neighborhoods Batista Campos (9), Canudos (17), Fátima (15), Nazaré (13), Reduto (12), São Brás (16) and Umarizal (14) did not show very significant densities. These neighborhoods are located in the historical region of the city, where the population presents a higher socioeconomic profile.

Another location with a low and very low density TB corridor is Ilha do Mosqueiro (53-71), at the vicinity of Baía de Marajó. This event can be justified by its low demographic density and migration of TB cases towards the central area of Belém in search of a better health assistance.

Figure 3 presents the location of the PHC units regardless of having notified TB cases during the period of this study. The clusters identified presented an average of two PHC units notifying the cases within the interpolation range. The neighborhoods of Tenoné (41) and Águas Negras (43), located in Distrito de Icoaraci, and the neighborhood Água Boa (52), in Distrito de Outeiro, presented medium and high density of TB cases, with non-notifier PHC units within interpolation range, which shows that the cases in these neighborhoods are being notified in other neighborhoods. Cases from Tenoné (41) and Águas Negras (43) were notified in neighboring neighborhoods, such as Coqueiro (38), Parque Guajará (40) and São João do Outeiro (50). The cases from the district of Água Boa (52) migrated to the healthcare unit from Cruzeiro (48), which is located in the same district, although it is not a nearby neighborhood.
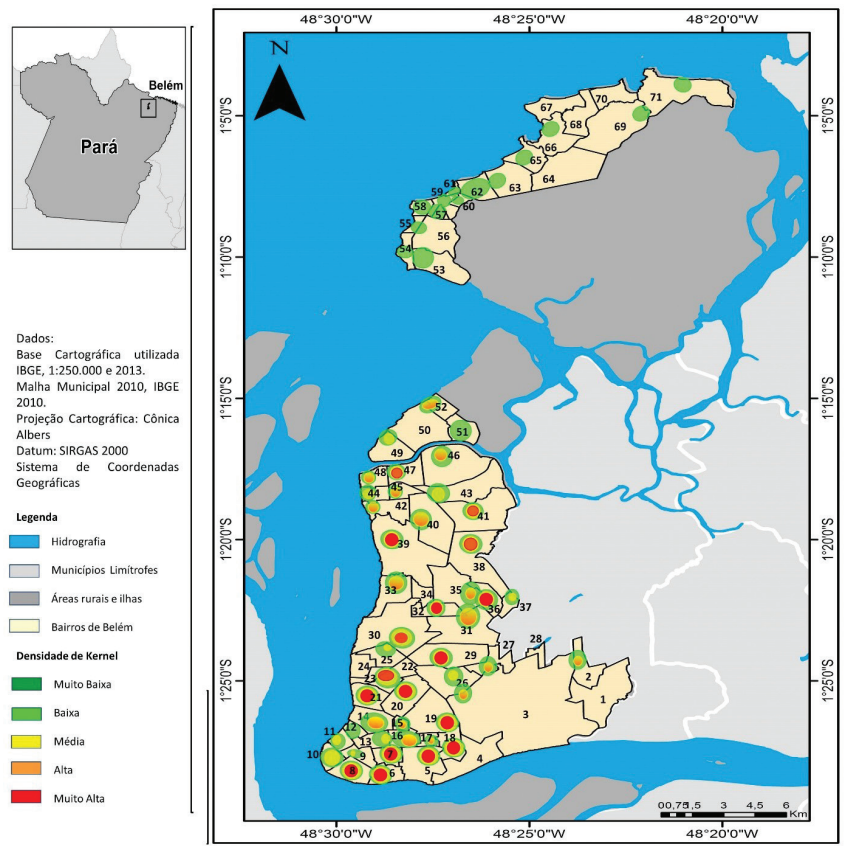

Figure 2 - Kernel Density in the neighborhoods of Belém during the period of 2010-2014, Belém, Pará, Brazil

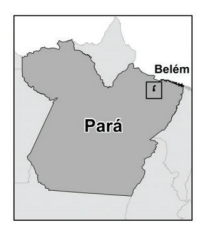

Dados:

Bados:
Bartográfica utilizada
BGE, 1:250.000 e 2013. Malha Municipal 2010, IBG 2010. Projeção Cartográfica:
Cônica Albers Cônica Albers
Datum: SIRGAS 2000 Datum: SIRGAS 2000
Sistema de Coordenadas Geográficas
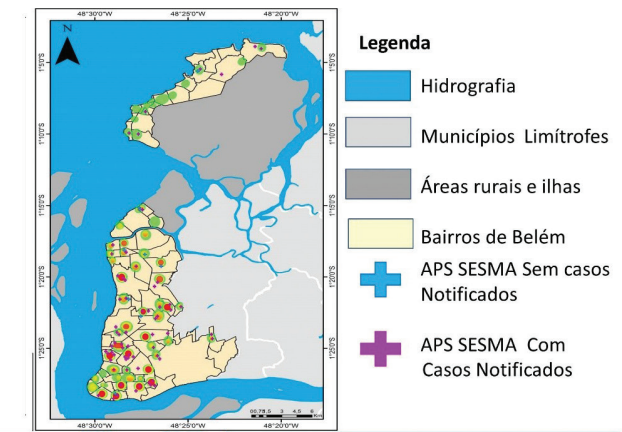

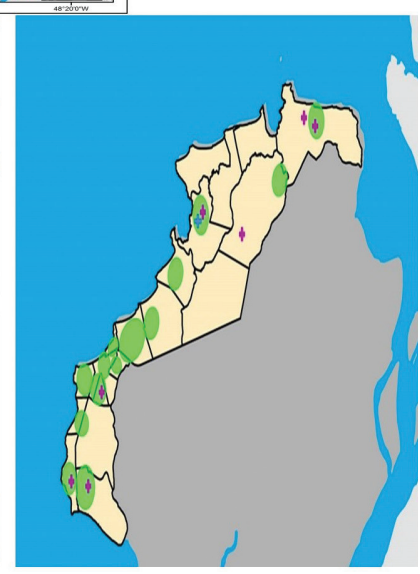

Figure 3 - Kernel Density and location of Primary Healthcare units from Belém, Pará, Brazil, 2010-2014 
The low density corridor located in the historical region of the city of Belém did not show any PHC units. The neighborhood of Marco (19) presented a PHC unit, however outside the interpolation range of the highest number of notified cases, which concentrated on the border of the neighborhood of Montese (18), a territory with great social vulnerability.

By analyzing the capital of Pará in its entirety by means of the global Moran index, a value of 0.042 ( $p$-value=0.195) was found, characterizing a positive spatial autocorrelation. However, the autocorrelation showed no statistical significance.

Table 1 - Number of resident and non-resident cases of notifier Primary Health Care units, Belém, Pará, Brazil, 2010-2014

\begin{tabular}{|c|c|c|c|}
\hline Neighborhood & $\begin{array}{l}\text { Cases of tuberculosis } \\
\text { in residents notified } \\
\text { in own neighborhood }\end{array}$ & $\begin{array}{l}\text { Cases of tuberculosis } \\
\text { in the neighborhood } \\
\text { notified in other } \\
\text { neighborhoods }\end{array}$ & $\begin{array}{l}\text { Notified cases of } \\
\text { tuberculosis in } \\
\text { residents from other } \\
\text { neighborhoods }\end{array}$ \\
\hline Aeroporto (57) & 6 & 1 & 31 \\
\hline Águas Lindas (2) & 56 & 5 & 0 \\
\hline Agulha (45) & 12 & 40 & 3 \\
\hline Baía do Sol (71) & 3 & 1 & 1 \\
\hline Barreiro (23) & 45 & 51 & 4 \\
\hline Benguí (32) & 161 & 22 & 31 \\
\hline Cabanagem (36) & 140 & 28 & 7 \\
\hline Carananduba (66) & 11 & 1 & 8 \\
\hline Condor (6) & 125 & 20 & 10 \\
\hline Coqueiro (38) & 91 & 27 & 79 \\
\hline Cremação (7) & 146 & 20 & 11 \\
\hline Cruzeiro (48) & 56 & 2 & 307 \\
\hline Curió-Utinga (3) & 52 & 17 & 27 \\
\hline Fátima (15) & 51 & 7 & 69 \\
\hline Guamá (5) & 372 & 41 & 28 \\
\hline Jurunas (8) & 355 & 23 & 59 \\
\hline Mangueirão (31) & 16 & 78 & 2 \\
\hline Maracajá (53) & 9 & 0 & 10 \\
\hline Maracangalha (25) & 0 & 14 & 14 \\
\hline Marambaia (29) & 282 & 40 & 216 \\
\hline Marco (19) & 135 & 66 & 176 \\
\hline Montese (18) & 256 & 24 & 21 \\
\hline Parque Guajará (40) & 43 & 15 & 18 \\
\hline Parque Verde (35) & 13 & 47 & 3 \\
\hline Pedreira (20) & 335 & 43 & 50 \\
\hline Ponta Grossa (44) & 9 & 28 & 29 \\
\hline Pratinha (33) & 63 & 20 & 1 \\
\hline Sacramenta (22) & 118 & 101 & 20 \\
\hline São João do Outeiro (50) & 38 & 7 & 70 \\
\hline Souza (26) & 3 & 28 & 0 \\
\hline Sucurijuquara (69) & 6 & 0 & 0 \\
\hline Tapanã (39) & 236 & 34 & 18 \\
\hline Telégrafo (21) & 234 & 31 & 145 \\
\hline Umarizal (14) & 1 & 61 & 101 \\
\hline Una (37) & 2 & 18 & 0 \\
\hline Val-de-Cães (30) & 97 & 12 & 53 \\
\hline Vila (54) & 0 & 6 & 1 \\
\hline
\end{tabular}

Table 1 shows the number of cases of TB according to the main residential neighborhoods. It is possible to identify that the neighborhoods of Aeroporto, Cruzeiro, Fátima, Maracajá, Marco, Ponta Grossa, São João do Outeiro and Umarizal presented a number of case notifications from other neighborhoods far superior to that of residents.

The neighborhoods of Agulha, Barreiro, Mangueirão, Parque Verde, Ponta Grossa, Souza, Umarizal and Una were unable to notify their local cases, since those migrated to other neighborhoods. The PHC units of the neighborhoods of Maracangalha and Vila did not notify any patient from the neighborhoods themselves. Residents of Vila were notified in Maracajá and Furo das Marinhas, and those of Maracangalha were all notified in PHC units of the neighborhood of Marambaia.

It must be noted that the neighborhoods Aeroporto, Benguí, Carananduba, Coqueiro, Curió-Utinga, Fátima, Maracajá, Marco, Parque Guajará, Ponta Grossa, Umarizal and Valde-Cães have an expressive amount of cases from other neighborhoods. Nevertheless, the existing cases in their own locality have migrated to neighboring neighborhoods.

\section{DISCUSSION}

The spatial distribution of TB cases was shown to be homogeneous during the period studied (2010-2014), not existing significant changes in number of cases. 2010 - 955 cases; 2011 - 1.115 cases; 2012 - 1.055 cases; 2013 - 1.084 cases; e 2014 1.085 cases. This way, it is possible to assume that health actions of the units or the life and environment conditions of these populations influenced in the decrease of TB cases.

Actions with major impact on TB control were established by the National Tuberculosis Control Program (PNCT) and are aimed at the decentralization of these actions for the various PHC units, the monitoring of indicators, health education in PHC units, and early diagnosis, thus preventing the spread of the disease. Although the PHC are the main units responsible for fighting against TB, the presence of an unit in the neighborhood does not mean better access to such services, which may be evidenced by the fact that 
the neighborhoods which had the highest number of TB cases are those with higher amount of PHC units (Figure 3).

In this study, it was also noteworthy the prevalence of TB in areas encompassing neighborhoods of lower socioeconomic conditions, located in the south and southwest of Belém i.e. areas with more social vulnerability, whereas the neighborhoods that showed fewer cases are the neighborhoods that, historically, have shown better living conditions, as well as in other Brazilian studies ${ }^{(10-13)}$.

When discussing TB, what is recommended is having an approach that goes beyond the characteristics of the clinic: the life condition of people must be considered, since discussion on how poverty favors the transmission of TB and the relationship of these people with $\mathrm{PHC}$ units is not recent. As long as the control of TB is considered only through the eyes of biomedical intervention, which is focused only finding the cure, prevalence and incidence rates in Brazil will continue to be high $^{(14)}$.

Another factor aggravating the incidence of TB is the migration between neighborhoods, caused by the search towards better health assistance, access to services and free care ${ }^{(15)}$. This fact is verified with the influx of residents from neighborhoods that do not have notifier PHC units or whose units do not have good physical infrastructure towards the neighboring neighborhoods that have better health care. This causes overcrowding of these units and, consequently, a repressed demand for assistance on the part of its own residents.

The health unit of the neighborhood of Marco (19) is located in an area that features better sanitation, no agglomeration of people, better air circulation - as it has a wooded region nearby - , which contrasts with the concentration of cases evidenced in the geographical space next to the neighborhood of Montese (18), which is characterized by an agglomeration of people and poor sanitation conditions. The neighborhood of Marco (19) has peculiar characteristics, having economically unequal areas. Since it is a reference unit far from the interpolation range where there is a concentration of cases, it receives more patients from other neighborhoods ( 176 cases) than from their own residents ( 135 cases).

It was possible to identify that the incidence rate of TB in a neighborhood influences the incidence of the neighboring neighborhood, which was identified by a global Moran index of 0.042 $(p=0.195)$, which represented a positive autocorrelation between neighborhoods; however, this autocorrelation does not show statistical significance. This way, the risks for transmission of TB in a region can be influenced by a TB epidemy in neighboring areas ${ }^{(16)}$. A study conducted in Campo Grande showed values with positive spatial autocorrelation between neighborhoods; however, it also showed no statistic significance for the period studied $(p=0.18)^{(17)}$.

Several studies investigated risk factors for TB, but few examined simultaneously the impacts of these factors on health services. In Belém, it was possible to observe that the clusters are near areas that presented notifying health units, namely, the TB cases tend to concentrate in the vicinity of the health service, as evidenced in Dabat, (Ethiopia), in which the areas identified with the highest number of cases are areas that offer the service of directly observed treatment short-course (DOTS) ${ }^{(18)}$. This can be explained by the fact that health services actively searches for symptomatic patients, which would increase the number of reported cases, or because the health unit conducts health education lectures, informing users about the clinical manifestations of TB and about when to seek health services.

It is worth mentioning that the geographic proximity of health services does not mean guaranteed access to diagnosis and efficient treatment. Oftentimes, health services accessibility is difficult, be it for work reasons or disease stigma, as well as the resistance of the user in seeking the service ${ }^{(8)}$. This can be exemplified when analyzing neighborhoods where the residents go towards other locations in order to acquire assistance and consequently being notified.

\section{Limitation of the study}

One limitation of this study was the fact it was conducted with secondary data, and thus there could be sub-notification. Another limitation regards this study being restricted to Belém (PA), which does not allow for the generalization of the results, but provides subsidies for further research.

Contributions to the field of nursing, health or public policy The findings of this research will contribute to the strengthening of TB control actions on the PHC, considering that it is in these units that searches for symptomatic patients with respiratory problems, diagnosis and treatment of cases occur. The nurse is part of the multidisciplinary team of the $\mathrm{PHC}$ and is historically a protagonist in fighting against TB.

\section{CONCLUSION}

Although studies on geographic distribution are recent in Brazil, the GIS is seen as one of the most used tools in spatial analysis of recent years, contributing to the planning, monitoring and analysis of health policies.

In the capital of Pará, the incidence of cases remained with little variation during the temporal progression analyzed, since the incidence of cases can be influenced by internal migration of symptomatic patients with respiratory problems seeking services that are geographically distant from their homes. It is believed that factors like the low solvability of the services can be determinant in this context.

It is worth mentioning the need for PHC units be able to handle cases in their neighborhoods, so that they can detect any cases of TB early, preventing the dissemination in the social environment and decreasing the incidence in the municipality.

\section{REFERENCES}

1. Barbosa IR, Pereira LMS, Medeiros PFM, Valentim RS, Brito JM, Costa ICC. Análise da distribuição espacial da tuberculose na região Nordeste do Brasil, 2005-2010. Epidemiol Serv Saúde[Internet]. 2013[cited 2016 Oct 1];22(4):687-95. Available from: http://scielo.iec.gov.br/pdf/ess/v22n4/v22n4a15.pdf 
2. Santos NSGM, Santos MLSG, Vendramini SHF, Villa TCS, Ruffino-Netto A, Chiaravalloti Neto F, et al. Tuberculose e análise espacial: revisão da literatura. Cienc Enferm[Internet]. 2014[cited 2018 Sep 12];20(2):117-29. Available from: https://scielo.conicyt.cl/pdf/cienf/v20n2/art_12.pdf

3. Coutinho LASA, Oliveira DS, Souza GF, Fernandes Filho GMC, Saraiva MG. Perfil epidemiológico da tuberculose no município de João Pessoa - PB, entre 2007-2010. Rev Bras Ciênc Saúde[Internet]. 2012[cited 2016 Oct 1];16(1):35-42. Available from: http://periodicos.ufpb.br/ojs/ index.php/rbcs/article/view/10172/7085

4. Ministério da Saúde (BR). Doenças infecciosas e parasitárias: guia de bolso. 8ª ed. Brasília, DF: Ministério da Saúde; 2010.

5. Ministério da Saúde (BR), Secretaria de Vigilância em Saúde. Perspectivas brasileiras para o fim da tuberculose como problema de saúde pública. Boletim Epidemiológico[Internet]. 2016[cited 2018 Sep 12];47(13):1-15. Available from: http://portalms.saude.gov.br/images/ pdf/2016/marco/24/2016-009-Tuberculose-001.pdf

6. Ministério da Saúde (BR). Sistema nacional de vigilância em saúde: relatório de situação. 5a ed. Brasília, DF: Ministério da Saúde; 2011.

7. Programa das Nações Unidas para o Desenvolvimento. O Índice de Desenvolvimento Humano Municipal Brasileiro. Brasília, DF: PNUD; 2013. 96 p. (Série Atlas do desenvolvimento humano no Brasil 2013).

8. Nardi SMT, Paschoal JAA, Pedro HSP, Paschoal VDA, Sichieri EP. Geoprocessamento em saúde pública: fundamentos e aplicações. Rev Inst Adolfo Lutz[Internet]. 2013[cited 2016 Nov 1];72(3):185-91. Available from: http://revistas.bvs-vet.org.br/rialutz/article/view/22284

9. Ministério da Saúde (BR), Conselho Nacional de Saúde. Resolução no 466, de 12 de dezembro de 2012. Diário Oficial da União[Internet]. 2013 Jun 13[cited 2018 Sep 13];1:59. Available from: http://bvsms.saude.gov.br/bvs/saudelegis/cns/2013/res0466_12_12_2012.html

10. Araújo KMFA, Gomes LCF, Pinto ML, Silva TC, Bertolozzi MR. Evolução da distribuição espacial dos casos novos de tuberculose no município de Patos (PB), 2001-2010. Cad Saúde Colet[Internet]. 2013[cited 2016 Nov 1];21(3):296-302. Available from: http://www.scielo.br/pdf/cadsc/ v21n3/v21n3a10.pdf

11. Montechi LN, Coelho DMM, Oliveira CAR, Campelo V. Distribuição espacial da tuberculose em Teresina, Piauí, de 2005 a 2007. Epidemiol Serv Saúde[Internet]. 2013[cited 2016 Nov 1];22(3):475-82. Available from: http://scielo.iec.gov.br/pdf/ess/v22n3/v22n3a12.pdf

12. Pinto ML. Padrões espaciais dos casos de tuberculose notificados no município de Cajazeiras/PB - 2001-2010[Dissertação]. Universidade Estadual da Paraíba; 2013. 23 p.

13. Hino P, Villa TCS, Cunha TN, Santos CB. Padrões espaciais da tuberculose e sua associação à condição de vida no município de Ribeirão Preto. Ciênc Saúde Colet[Internet]. 2011 [cited 2016 Oct 1];16(12):4795-802. Available from: http://www.scielo.br/pdf/csc/v16n12/28.pdf

14. Braga JU, Herrero MB, Cuellar CM. Transmissão da tuberculose na tríplice fronteira entre Brasil, Paraguai e Argentina. Cad Saúde Pública[Internet]. 2011 [cited 2016 Dec 1];27(7):1271-80. Available from: http://www.scielo.br/pdf/csp/v27n7/03.pdf

15. Zhao F, Cheng S, He G, Huang F, Zhang H, Xu B, et al. Space-time clustering characteristics of tuberculosis in China, 2005-2011. PLoS ONE[Internet]. 2013[cited 2016 Dec 1];8(12):e83605. Available from: http://journals.plos.org/plosone/article?id=10.1371/journal. pone.0083605

16. Queiroga RPF, Sá LD, Nogueira JA, Lima ERV, Silva ACO, Pinheiro PGOD, et al. Spatial distribution of tuberculosis and relationship with living conditions in an urban area of Campina Grande - 2004 to 2007. Rev Bras Epidemiol[Internet]. 2012[cited 2016 Nov 1];15(1):222-32. Available from: http://www.scielo.br/pdf/rbepid/v15n1/en_20.pdf

17. Randremanana RV, Sabatier P, Rakotomanana F, Randriamanantena A, Richard V. Spatial clustering of pulmonary tuberculosis and impact of the care factors in Antananarivo City. Trop Med Int Health[Internet]. 2009[cited 2016 Oct 1];14(4):429-37. Available from: https://www.ncbi. nlm.nih.gov/pubmed/19228353

18. Tadesse T, Demissie M, Yemane B, Kebede Y, Abeb M. The clustering of smear-positive tuberculosis in Dabat, Ethiopia: a population based cross sectional study. PLoS ONE[Internet]. 2013[cited 2016 Dec 1];8(5):e65022. Available from: http://journals.plos.org/plosone/ article?id=10.1371/journal.pone.0065022 